\title{
Driving Model of Determinant Factors Affecting the Performance of Small and Micro Enterprises: Empirical Evidence from Amhara Region, Ethiopia
}

\author{
$1 *$ Professor Zhang Youtang, ${ }^{2}$ Ayele Eshetu Yesuf \\ ${ }^{1}$ Department of Management, Wuhan University of Technology, Wuhan, P.R.China, 430070 \\ ${ }^{2}$ School of Management, Wuhan University of Technology, Wuhan, P.R.China, 430070 \\ (E-mail: zyt@whut.edu.cn), (E-mail: eshetu9361@gmail.com
}

*Corespondence:_Ayele Eshetu Yesuf Tel. Number +8615623905063

\begin{abstract}
The purpose of this study is to examine the driving model of determinant factors that affects the performance of small and micro enterprises empirical evidence from Amhara Region, Ethiopia. The study used primary and secondary data from manufacturing, construction, urban agriculture, trade, and service entrepreneurs found in Bahirdar, Dessie \& Gonder Cities using a purposive sampling technique. It also used the descriptive research design with a self-administered survey questionnaire. The Statistical analysis tools, SPSS and Amos, software were applied to analyze the data. Multiple regression model results revealed that access to credit, initial capital, working premises, industry category, market linkage, ICT adoption have a positive relationship and a major impact on the Amhara region's enterprise performance. Hence, the outcome variable, enterprise performance, is highly affected by all predicted variables. As the study finding shows, a lack of access to credit, , market linkage, working premises), initial capital, and information communication Technology problems are critical challenges of SMEs. The Regional Government, TVED Bureau, Micro Finance Institutions, , should take corrective action to provide sufficient credit and long-term loans to protect inflation. Moreover, this study proposed a sustainable cluster management approach that solves their challenges in an integrated way.
\end{abstract}

Keywords: Enterprise Performance; Market Linkage; Credit Access; Working Premises; SME

\subsection{Introduction}

Existing evidence to date indicates that small and micro enterprises' (SMEs) ' performance is a critical component of sustainable development in developing economies [1,2]. Small and micro enterprises (SMEs) play an essential role in the economy, especially in employment, development, productivity, and poverty alleviation [3]. This sector's importance in Ethiopia is noted in various documents, such as industrial policy, the SMEs Development Strategy, and the I and II Growth and Transformation Plans, to accelerate growth and reduce poverty [4]. However, both the level of unemployment and the quality of job creation remain a concern. Simultaneously, growth and improvement have strongly underlined its various development plans through its elevation [5]. Several factors have continuously challenged these companies' activity and growth; even several companies in different parts of the country have collapsed and are out of business. [6]. A systematic and frequent study at the global, regional and corporate levels is necessary to provide result-oriented and sustainable support to the sector to reduce unemployment challenges and identify growth determinants $[7,8]$. Therefore, various studies were conducted to classify performance determinants in different parts of the world. It involves the studies conducted By [9] [10,11]. However, most Ethiopia studies, including the Amhara region, do not provide clear findings or address SMEs' development determinants.

According to research in Ethiopia [12], the low market climate also affects enterprises' performance. In particular, frequent power shortage, lack of access to credit, and water scarcity are inversely correlated with SME's performance. Access to credit continues to be the biggest challenge for SMEs, as these enterprises are too large for non-bank financial institutions. At the same time, commercial banks are too weak, illustrating the lack of intermediate financial intermediation. The key finding of this analysis is that the SMEs' start-up size and development are negatively linked, which means that SMEs that start businesses larger in terms of jobs grow slower than their counterparts. This result is consistent with the company's relatively recent learning model; when businesses grow older or grow more prominent, their growth rate decreases because they are already at a higher productivity level. [12] that descriptively analyzed the difficulties and efficiency of SMEs, neglecting inferential statistics. Secondly, [13] conducted a study that examined the role of financial institutions in the growth of only 57 sampled companies using percentage changes in assets as a growth proxy.

Furthermore, this review only included access to credit, enterprise size, and firm age to investigate factors affecting growth, ignoring more variables discussed in the literature of performance constraint variables. In the same vein, empirical studies have been carried out in different parts of the world, separately from the Ethiopian background, to identify the factors that affect SMEs' performance. However, the resistance of development, although the effect and magnitude of enterprise performance variables differ From country to country, area to area, and from region to region.

\subsection{Statement of the problem}

According to the study by [1], small and micro enterprises (SMEs), they are considered to significantly impact the social and economic growth and the backbone of each country's economy. Much of today's primary businesses are made up of SMEs, as the 
core of a county's economy, and assist larger companies in the form of subcontractors, manufacturers of natural products, or consumers. Research conducted by [14] small and micro enterprises (SMEs) play an essential and vital role in today's global economy and are recognized as one of the main contributors to economic, national, and job growth. According to [15], small and micro-sized enterprises (SMEs) are 99 percent of all European companies, and 66 percent of the jobs in Europe were generated between 1985 and 1995. According to [16], SMEs are also estimating their work imperfections in Africa. It stands at 50 percent, with a correspondingly high contribution to most African economies' general productivity natural home of entrepreneurship is defined as small and micro enterprises (SMEs). The SME sector is believed to be the primary source of employment and income generation for a larger community group, according to Ethiopia's study [17]. The business contributes 3.4 percent of GDP, 33 percent of the industrial sector's contribution, and 52 percent of the manufacturing sector's 2001 Growth and transformation plan(GDP) contribution [18].

The South Nation National Peoples Region is the leading innovative commercial center for small and micro-enterprises [19] South Nation National Peoples Region. The Administration of the Government of the South Nation of the National Peoples Region and Hadiya Zone set out areas for job development activities and projects, including external funding for donors, such as small and micro-enterprises. According to [20] Conducted in his research, microfinance institutions' role towards small and micro-enterprise (SME) performance is crucial for economic growth and development. It recognizes that the accessibility of capital is essential for speedy implementation. Microfinance institutions (MFIs) are regarded as financial instruments for reducing poverty, solving the unemployment problem, and stimulating growth and economic development in developing countries. MSEs are usually faced with multiple challenges in these nations. The primary one is access to micro-financing, which is considered a crucial component of any business. Microfinance has taken an essential part in the growth process in the context of the area of Amhara. Microfinance was established to extend access to financial products to micro and small business owners with a low level of revenue. It also provided term loans as well as repayment loans. Credit access has shown to be a major challenge for entrepreneurial growth by helping SMEs, especially small and micro-enterprises that do not have access from traditional sources, notably banks, to tackle funding constraints and lack of access to credit. However, SMEs have an obstacle to access to credit and services from microfinance institutions, particularly in the Amhara region, incapable of collateral and long-term supply processes. Finally, in the Amhara region, microfinance would positively impact such outcomes that its effect exceeds the borrower's economic and social change. However, the county's development is affected by socio-cultural and political problems, the lack of enterprise culture, and a positive attitude toward society for small and micro-enterprises. This research will play a determinant factor in evaluating the effect of small and micro-enterprise performance in the Amhara region.

\subsection{The objective of the study}

The research's main objective is to examine the determinant factors affecting small and micro enterprise (SMEs) performance evidence from Ethiopia's Amhara region.

\subsection{Specific objective}

- To examine the factors affecting small and micro enterprise (SMEs) performance,

- To analysis the effects of all study variables on enterprise performance,

- To investigate the relationship between independent \& outcome variables,

- To explore the model for micro and small enterprises for future enterprise performance improvement,

\subsection{Research questions}

- What are determinant factors affecting small and micro-enterprise performance in the Amhara region?

- What are the effects of variables on enterprise performance?

- Is there a relationship between independent $\&$ outcome variables,

- To what extent the proposed model fit with the determinant factors on enterprises performance,

\subsection{Research Hypothesis}

1) $\mathrm{H}_{1}$ : Marketing linkage is positively associated with Micro and small enterprise performance

2) $\mathrm{H}_{1}$ : Credit access is positively related to small and Microenterprise performance

3) $\mathrm{H}_{1}$ : Access working premises is positively associated with micro and small enterprise Performance

4) $\mathrm{H}_{1}$ : Initial capital is positively associated with micro and small enterprise performance

5) $\mathrm{H}_{1}$ : Information and communication technology is positively associated with enterprise performance.

\section{Literature review}

\subsection{Theoretical perspectives}


There are currently two dominant theories on SMEs' performance determinants: the model of industrial organization and a view centered on capital. Instead of resources and skills internal to the business, the industrial organization model sees companies' performance from an external viewpoint: environmental/external variables, as a dominant position in its development and strategic behavior [21]. According to this model, a business enterprise must first consider the external environment (the market in which it operates) and look for the most appealing to the company and build a strategy that matches the industry's characteristics. On the other hand, the resource-based viewpoint considers that the specific resources and skills owned and managed by each organization are the sources of capacity to produce an above-average return or higher growth than competitors. It must then effectively execute the strategy to improve its competitiveness level such that it makes the above-average return. The resource-centered view is based on the argument that all businesses face the same external climate. However, organizations with good internal potential (tangible and intangible resources) take advantage of environmental possibilities and overcome external risks and challenges. It means that, while companies with unique resources and capabilities gain superior income, companies with marginal resources can only hope to break even [22].

\subsection{Small and micro-enterprise Definition in Ethiopia}

The concept of micro and small enterprises in the past was based solely on paid-up money. If its paid-up capital is less than or equivalent to Birr 20,000, an enterprise is classified as micro. Likewise, when its paid-up capital is less than or equal to Birr 500,000, an enterprise is considered small. However, this does not include details on the size of jobs or the number of SMEs' employees. It also did not indicate the SMEs' total asset size and did not distinguish between manufacturing (industry) and services. The new Definition considers human resources and assets as the key steps to overcome the shortcomings of the old Definition of micro and small enterprises [23].

\begin{tabular}{|l|l|l|l|}
\hline Type of the Enterprise & Sector & Number of employees & Total Asset \\
\hline Microenterprise & Industry & $<5$ & $<100,000($ Birr $)$ \\
\hline Microenterprise & Service & $<5$ & $<50,000$ (Birr) \\
\hline Small enterprise & Industry & $6-30$ & $<1.5$ million (Birr) \\
\hline Small enterprise & Service & $6-30$ & $<500,000$ (Birr) \\
\hline \multicolumn{2}{|r|}{ Table 1 Definition of small and micro-enterprise in Ethiopia }
\end{tabular}

Source: FeMSEDA, 2011

According to [6], microfinance institutions' role showed that the growth rate for small and micro enterprises (SMEs) whose owners were trained and whose initial capital was high was better than those whose owners/operators were not trained. Entreneures who started with low capital, worked in the manufacturing sector, and worked in cooperatives or were not trained were better than those whose owners/operators were not trained. Consequently, government officials, non-governmental organizations, and other national economic development actors must work hand in hand in small and micro enterprise (SMEs) training, finance accessibility, training, and business sectors. The small business sector is an important part of economic growth and a key factor in lifting nations out of poverty [24]. In developing countries, small and micro enterprises are a driving force for economic development, job creation, and poverty reduction. Besides, small companies have been identified as a feeder operation for large-scale industries [25]. Because of this, Ethiopia's Micro and Small Enterprise Growth Program has received sufficient government attention since 2004/2005. Until 2004/2005, the Federal SMEs Development Agency, structured only at the state level, introduced the national strategy. Thus, it was tough to make the approach realistic, especially in providing MSE operator business development services. Thus, taking into account the critical position of the sector and the challenges facing MSE operators since 2004/2005, Ethiopia's Government has agreed to set up a regional level coordinating body for SMEs

\subsection{Small and micro-enterprise Empirical Evidence in Amhara region}

Amhara regional state is one of Ethiopia's biggest regions, located in the northwest, with 22 million. In small and micro enterprises (SMEs), several common determinants affecting enterprise performance were too limited. According to [26], different challenges have created an obstacle for SMEs in creating job opportunities and expanding their business in Debrebrehan Town. These include lack of finance (79.5 percent), marketing issues (75.5 percent), lack of sufficient room for work and sales (75.2 percent), infrastructural challenges (72.9 percent), input challenges (70.7 percent), structural and management challenges (75.2 percent) (68.6 percent), City management challenges (65.4 percent) and technical challenges (61.7 percent).

To SMEs enhancement strategies, it is essential to recognize each organization's problems at various locations. It is because, while MSE has some common challenges, challenges are both company and location-specific.

According to [27], micro and small enterprises in furniture production face several factors affecting their success. Some companies struggle to sustain; some remain without transformation for an extended period, and most manufacture identical objective is to enhance SMEs' performance and contribution. A questionnaire, a group discussion with experts, and an interview process were used to collect data. 
Eight randomly selected significant cities in the Amhara area with 120 furniture manufacturing companies are deemed chosen randomly; SPSS tools (correlation, proximity, and T-test) and impact-effort analysis matrix tools were used for data analysis and presentation. Correlation analysis revealed that the variables result in a strong correlation with Pearson correlation values of $\mathrm{r}=$ $0.988,0.983$, and $\mathrm{r}=0.988$ Politico-legal with infrastructure, leadership with entrepreneurial expertise, and marketing considerations for finance and credit.

Marketing and related factors could be related to Politico-legal factors, infrastructure factors, finance and credit factors, working factors areas and associated factors, raw materials and related issues, technology, and related aspects with proximity ranges of 0.914 $0.154,0.278,0.842,0.407$, and 0.211 . Marketing and associated factors are almost related to other factors and have very beneficial effects on business performance. The proximity gap shows that the solution of all raw materials, technology, working areas, finance and credit, infrastructure, and politico-legal factors would be a significant factor for market share and related issues. Few initial capitals, company position, sectoral commitment, land access, business experience, owner gender, owner motivation, education, market connection, business to business, consequently.

The above context indicates at least three reasons why additional research in SMEs is required in Ethiopia in general and the Amhara region in particular. First, various factors have persistently challenged SMEs' performance; many companies have collapsed and exited in different parts of the country. Small and micro enterprises (SMEs) in the Amhara region are no exception to this, certainly.

The second, common factors associated with small micro enterprises(SMEs) have been established in past empirical studies in different countries. Factors' impact and magnitude vary from one arena to another, presenting exact results that cannot be generalized and require more research. Thirdly, current studies on SMEs' determinant factors focus primarily on developed regions in the Amhara region. In addition to mixed findings that leave study gaps, less evidence is reported in different study areas. This research's objective was to analyze, against this backdrop, the performance of small and micro enterprises and their driving factors.

This paper's uniqueness is that, unlike the current studies. It integrated demographics, firm details, and external factors to fill the void in the limited SMEs' growth literature as an Amhara region. Most notably, the paper attempted to address determinant factors that affect small and micro-enterprise performance in Amhara region Dessie Gonder and Bahirdar city

\subsection{Research gap}

According to [28, 29], research demonstrates Ethiopia's missing middle phenomenon. It is a common characteristic of many micro-enterprises and some large businesses in many developed countries, but far fewer small and micro-enterprises. SMEs account for more than 50 percent of GDP and more than 60 percent of jobs in high-income countries, but they account for less than half of that in low-income countries: 30 percent of employment and 17 percent of GDP. From the research, we can see the previous study's gaps depend only on profitability and do not explain Enterprise performance. It implies country growth in general.

This research paper aims to analyze determinant factors affecting small and Microenterprises performance, including the level of transition, enterprise formation, and employment creation, particularly in the Amhara region. Several studies in the Amhara region were too limited in small and micro-enterprises. Several common determinants affect enterprise performance. According to [26], different challenges have created an obstacle for SMEs in creating job opportunities and expanding their business. The independent variables that determine the performance of enterprise performance were selected and analyzed in this research paper. The independent variables are record keeping, financial management factor, marketing factor, access working premises (location) factor, Initial capital factor, industry category factor, ICT adoption factor, and access credit factor.

\subsection{Measuring Variables}

Enterprise performance can be measured by developing enterprises, job creation, and the transition from one stage to the next. Based on this statement, the researcher follows it. Additionally, the business transition from one step to the next step shows enterprises' performance through job creation and their current capital. The key challenges of internal variables influencing small and micro-enterprise sustainability are independent variables, such as gender, education, record keeping, financial management practice, initial capital, credit access, industry category, information communication technology, and workplace (location) marketing factors.

\subsubsection{Education factor}

Training is presumably connected to knowledge and skills, inspiration, self-confidence, capacity to solve problems, determination, and discipline. It is anticipated that higher education will increase the ability to cope with challenges and exploit opportunities [30]. The position of growth education is clarified by its effect on exposure to new knowledge and processing that could positively impact the manufacturing and disposal of products and services [31]. Furthermore, it is assumed that operators with higher education qualifications are likely to make better quality decisions to run a business to decrease the probability of failure [32]. Therefore, companies with higher formal education owned and operated by entrepreneurs experience greater development than their counterparts [33].

\subsubsection{Working premises (Location)}

Relative to those located in rural areas, it is suspected that companies located in urban areas tend to expand faster because urban companies have access to a broad consumer market. High buying power compared to companies operating in rural areas [5, 34]. 
Besides, companies located in urban areas have access to public infrastructure that includes water, electricity, highways, telecommunications, electronic media, and postal services, all of which, regardless of their size, are crucial for business start-ups, development, and growth $[35,8,36]$. In other words, it means that businesses that operate in a world with weak infrastructure that is incapable of accessing markets, communications, power, and water and barriers to entry and impede competition are slowly increasing relative to their counterparts with better infrastructure [37,38]. Compared to those set up in privately leased premises, companies operating in premises allocated by government agencies had a greater chance of survival [31]: Innumeracy, illiteracy, and lack of business skills. Women are also more risk-averse, and fewer growth-oriented networks are part of [39]. Furthermore, it may be due to customer concentration in small growing Sectors such as exchange and service [40].

\subsubsection{Initial capital Factor}

It is noted that companies starting their businesses are more likely to expand higher initial capital than their peers who have started their business with a relatively lower initial investment [5]. The research paper shows a positive relationship between initial capital and business performance on the determinants of SME growth in Ethiopia, the case of Bahirdar City.

\subsubsection{Industry category}

In Ethiopia, it is assumed that the manufacturing and construction sectors are rising faster than other sectors because the country's industrial growth problem is manufacturing [5]. Moreover, in the Ethiopian context, production, especially metal and woodwork and construction, tends to be more competitive than other sectors. It may be linked to the sectors' skills and experience [41].

\subsubsection{Marketing factor}

Companies can have forward ties with consumers or other resellers and backward links with their raw materials suppliers to get the materials required to manufacture products or serve vices [38]. That means that the equal supply of raw materials ensures profitable company growth, and the unavailability of raw materials can be a growth obstacle. Therefore, business linkage and companies' evolution have positive relationships [40].

\subsubsection{Information and communication technology Factor}

The implementation of technology for information and communication (ICT) captures the use of electronic products/services such as websites, online sales, and computerized production systems [42]. Accordingly, companies using ICT are believed to develop faster than their counterparts because using ICT will enhance and deepen customer relationships, improve company image, improve Exchanging knowledge, and compete with other companies [ 30,41]. Also, having a social network is a valuable tool that can help entrepreneurs access data and credit tools. Social networks can play a larger role in assisting companies in resolving challenges associated with transaction costs, contract compliance, and regulation [36].

\subsubsection{Access to credit factor}

Credit availability ensures the smooth functioning of businesses as it injects working capital. Therefore, the risk of company failure is low if access to financing is open [32]. SMEs who have access to finance are rising stronger than those with capital shortages [31]. In other words, companies with minimal growth opportunities for debt funding are lower than those that are enterprises.

\subsubsection{Microfinance Efficiency}

According to [40], the width measurements include the number of customers served by the MFI and its portfolio size. The bigger these steps are, the more the MFI generates outreach. But we are also interested in creating these statistics [43]. In particular, the loan portfolio, the level of savings, the number of credit customers, and the number of savings customers and their growth rates are analyzed. Based on this empirical evidence, the researcher design the microfinance efficiency can be evaluated by loan outreach, borrowers of clients, saving mobilization, repayment of the loan, and loan distribution for SMEs. This micro-finance efficiency to give useful service was very critical for enterprise performance.

\subsection{Conceptual framework}

The conceptual structure demonstrates relationships between independent and dependent variables. Since certain variables decide SMEs' performance, it is important to evaluate interactions to achieve SMEs' expected performance. The independent variables are initial capital, industry category, market linkage, working premises( location), access credit, and ICT adoption. 


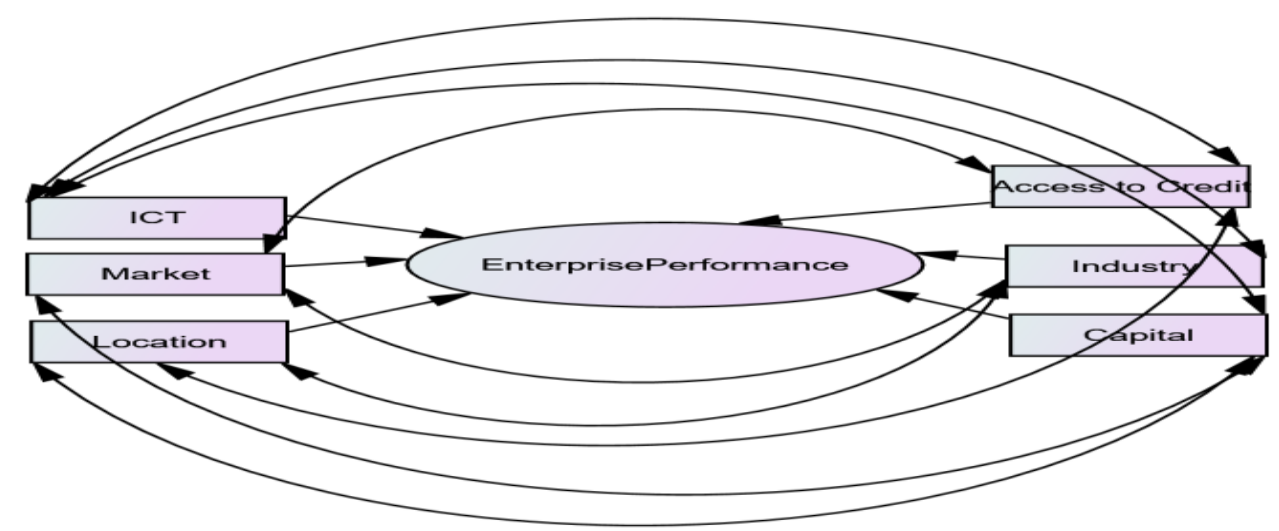

Fig1 conceptual framework

\section{Research methodology}

\subsection{Research design}

Research design is the road map for achieving research objectives and addressing research issues [44]. Researchers may choose between different types of possible research designs, as an architect chooses among the possible construction designs depending on the building's purpose, construction method, construction time, and other relevant factors $[45,46]$. Therefore, this study's research design is descriptive and explanatory research methods. The research approach is focused upon a quantitative and qualitative research methodology.

\subsection{Data collection instruments}

The research analysis utilized both primary and secondary data. The preliminary data collected and used from the selected small and micro-entrepreneurs respondents, and the secondary data collected from the Technical and Vocational Enterprise Development (TVED) Bureau 10 year strategic regional government performance from 2011-2020. The financial data also collected from Amhara Credit and Saving Institution (ACSI) from 2011- 2020. The method of collecting primary data was five-point Likert scale questionnaires. The questionnaire was Closed and open-ended from the available studies [8,11,5]. Besides, the instrument's reliability. Validity can be evaluated in quantitative testing. Reliability is the degree to which a construct's measurement is accurate, and validity tests how well a given measurement scale calculates the theoretical construct it is supposed to calculate. [47].

\subsection{Population, sample size, and methodology for sampling}

According to [48], the ever-increasing Study demand has generated a need for an effective method of determining the sample size required to choose to represent a given population. Based on this study used the following formula to select the sample size depending on the estimated population.

$$
S=x^{2} N P(1-P)+d^{2}(N-1)+x^{2} P(1-P)
$$

Where

$\mathrm{S}=$ required sample size

$\mathrm{X}^{2}=$ the table value of chi-square for 1 degree of freedom at the desired confidence level (3.841

$\mathrm{N}=$ the population size

$\mathrm{P}=$ the population proportion (assured to be 0.05 since this would provide the maximum sample size) 
$\mathrm{d}=$ the degree of accuracy expressed as a proportion $(0.05)$

\begin{tabular}{|l|c|c|c|c|c|c|}
\hline Study area & $\begin{array}{c}\text { Manufacturi } \\
\text { ng }\end{array}$ & $\begin{array}{c}\text { Constructio } \\
\text { n }\end{array}$ & $\begin{array}{c}\text { Urban } \\
\text { agriculture }\end{array}$ & Trade & Service & Total \\
\hline Bahirdar City & 40 & 30 & 20 & 25 & 15 & 130 \\
\hline Gonder City & 35 & 25 & 30 & 15 & 5 & 110 \\
\hline Dessie city & 70 & 13 & 35 & 10 & 15 & 143 \\
\hline Total & 145 & 68 & 85 & 50 & 35 & 383 \\
\hline
\end{tabular}

Table 2 population sample size

Therefore, $\mathrm{S}=(3.841)^{2} 76536 \times .50(1-.50)+(0.05)^{2}(76536-1)+(3.841)^{2} .50(1-.50)$

The required sample size $=383$

Table 2 the research sample size determination distributed using purposive sampling technique for three cities: Bahirdar, Gonder \& Dessie Cities Small, and micro-enterprises.

\subsection{Measurement of variables and model specification}

Although defining an empirical model, identified dependent and independent variables with their measurement are no preference. The dependent variable of the current analysis, the performance of SMEs, depends on the entrepreneur's performance. The empirical model's independent variables were initial capital, location, enterprise and market linkage, ICT adoption, and access credit. Empirical studies provide various representations for small and micro-enterprise development.

The enterprise performance was measured using total assets, revenue, size of employment, benefit, and capital growth [5]. The interventions rely on the easiness of data availability and the researcher's reasonable judgment. The employment growth is used in the evolution of SMEs in Ethiopia, which looked at work development and employment size data [49,50,5]. Furthermore, providing systematic indicators is a safe way of assessing growth rather than relying on a single predictor [11]. Jobs and capital growth rates were therefore considered as the best-suited steps for the growth of enterprises to comply with the country's strategic plan for industrial development and the concept criteria of SMEs.

In most growth-related research, both the multiple linear regression and binary logistic regression models were applied. For example, in their studies [11], Ethiopia used the binary logistic regression model. Therefore, in growth-related experiments, both logistic and multiple regressions may be used. The general multiple linear regression model that followed is defined in the current study in line with $[50,44,5]$ as businesses' growth is regarded as a continuous variable. Gujarati \& Porter (2009,p:849) revealed that more than two and three variables multiple linear regression models, the K-variables population function model involving the dependent variable $\mathrm{Y}$ and $\mathrm{K}-1$ explanatory variables $\mathrm{X}_{2}, \mathrm{X}_{3}, \ldots \mathrm{X}_{\mathrm{k}}$ as the following equation.

$\mathrm{Y}=\mathrm{a}+\mathrm{b} 1 X 1+\mathrm{b} 2 X 2+\mathrm{b} 3 X 3+\mathrm{b} 4 X 4+\mathrm{b} 5 X 5+------+\mathrm{bn} X \mathrm{n}+\mathrm{e}$

Where

$\mathrm{Y}=$ enterprise performance, $\mathrm{a}=$ constant (y-intercept), regression coefficient attached to variable $X 1, X 2, X 3$ and $\mathrm{X} 4 \ldots .+\mathrm{bn} X$ $\mathrm{n}+\mathrm{e}$. Independent variables that contributed significantly to Variance of enterprise performance .

$E N P R=\mathrm{a}+X 1 I A W P+X 2 I C A P+X 3 I C T+X 4 \mathrm{ICA}+X 5 A C F+X 6 M L I+e$

Where the ENPR = Enterprise performance,

$\mathrm{X} 1, \mathrm{AWP}=$ access working premises

$\mathrm{X} 2$, ICAP=Initial capital

$\mathrm{X} 3, \mathrm{ICT}=$ Information communication technology

$\mathrm{X} 4, \mathrm{ICA}=$ Industry category 


$$
\begin{aligned}
& \text { X5. } A C F=\text { Access credit factor } \\
& \text { X6. } M L I=\text { Marketing linkage factor, } \\
& \text { e = Error term, n represents the number of firms, } \\
& \quad X=\text { to estimate multiple regression coefficients }
\end{aligned}
$$

\section{Data Analysis and Interpretation \\ 4.1 Demographic Variables Analysis}

Analysis of demographic variables from the respondent's sex, age, and education shows $295(77 \%)$ of respondents are male, and $88(23 \%)$ respondents were female entrepreneurs. Female entrepreneurs are less than male entrepreneurs from the data. According to the entrepreneur age, the outcome also showed that most entrepreneurs are young and a productive labor force; the sector is fulfilling one of the government's goals by generating job opportunities for young people. Such a healthy population is assumed to be an engine for the region's growth and the country. From the findings, 25 years and below 83(22\%) from 26 to 35 years 139 (36\%) from 36 to 45 years 101(26\%) from 46 to 55 years 60 (16\%). This result indicates that most entrepreneurs are between 26 and 35, which implies a more productive age group and a significant workforce for enterprise performance. In addition education background high school graduates 167(44\%) TVET 181 (47\%) Degree 29(8\%) Master $6(2 \%)$. The result may infer from this study that most of the entrepreneurs are TVET graduates and help improve enterprise performance.

\subsection{Enterprise transition performance}

Fig 2 below the TVED bureau from 2011-2020 report shows on Enterprise transition performance evaluation trend. The transition of enterprises from one step to the next step is based on enterprise capital \& employment growth. The trend indicates that the actual performance of manufacturing 4580 (93\%), Construction $1179(100 \%)$, urban agriculture $805(120 \%)$, trade 3093 (86\%), service 2943 (82\%), total $12600(90 \%)$.

Based on this outcome, the achievement of enterprise performance was excellent and promising. Enterprises due to the growth stage, the sustainability of their business performance was good. However, when we look forward from the number of total enterprise formation stages in the Amhara region shown in the previous analysis, the whole enterprise formed 267,981 actual performance 13,966 (5.2\%) transitioned from one step to the next was deficient performance. That means many enterprises are fading at the foundation stage due to lack of finance, lack of market factors, lack of working premises, and lack of financial management problems.

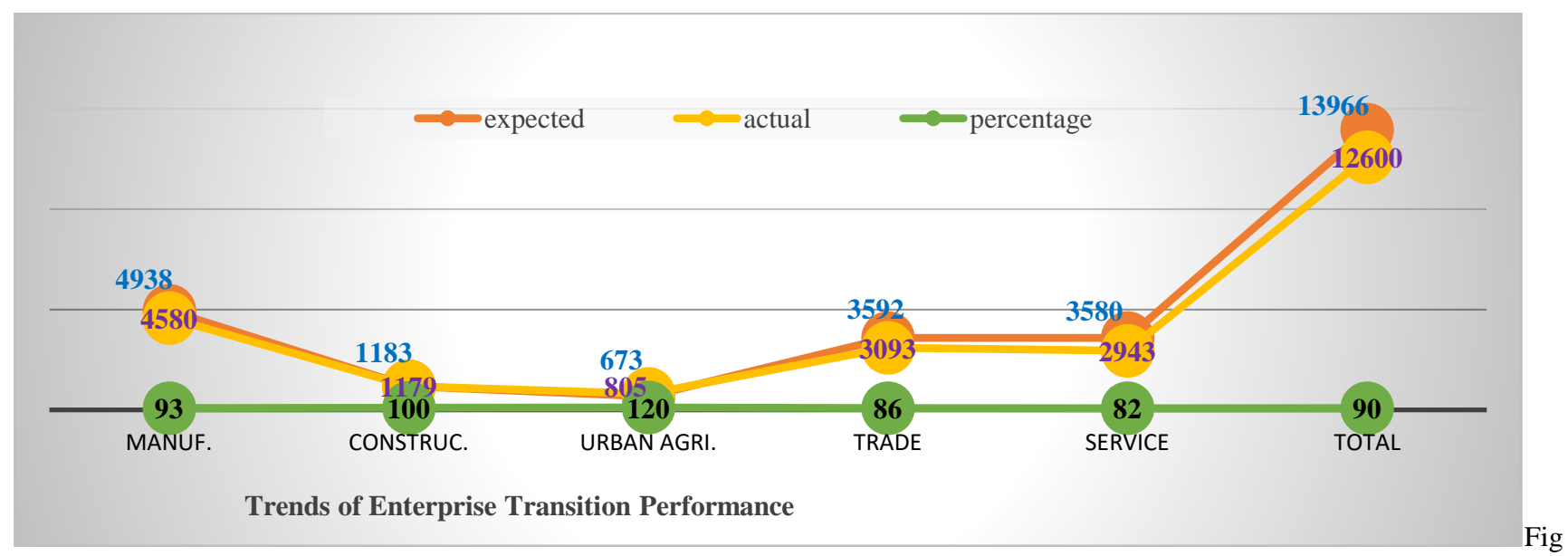

Enterprise transition performance

In Fig 3 below, the result shows from 2011-2020 based on five industry category from expected to actual performance such as manufacturing enterprises performance from 154874 to (49\%), Construction 91735 to (40\%), Urban Agriculture 64334 to (63\%), Trade 69622 to (70\%), Service 102259 to (68\%), Total 482824 to (55\%) respectively. It implies all industries contribute to the formation of enterprises, employment creation, and country economic growth. From the total job creation result, it is possible to conclude that urban agriculture and trade sectors achievement improved performance than manufacturing and construction. Because of the absence of accessibility constraints for finance and technology, construction 
and manufacturing companies reduced production rather than urban agriculture, trade, and service enterprises. From the respondents' response. Manufacturing and construction industry's need a high amount of initial capital to run their business correctly.

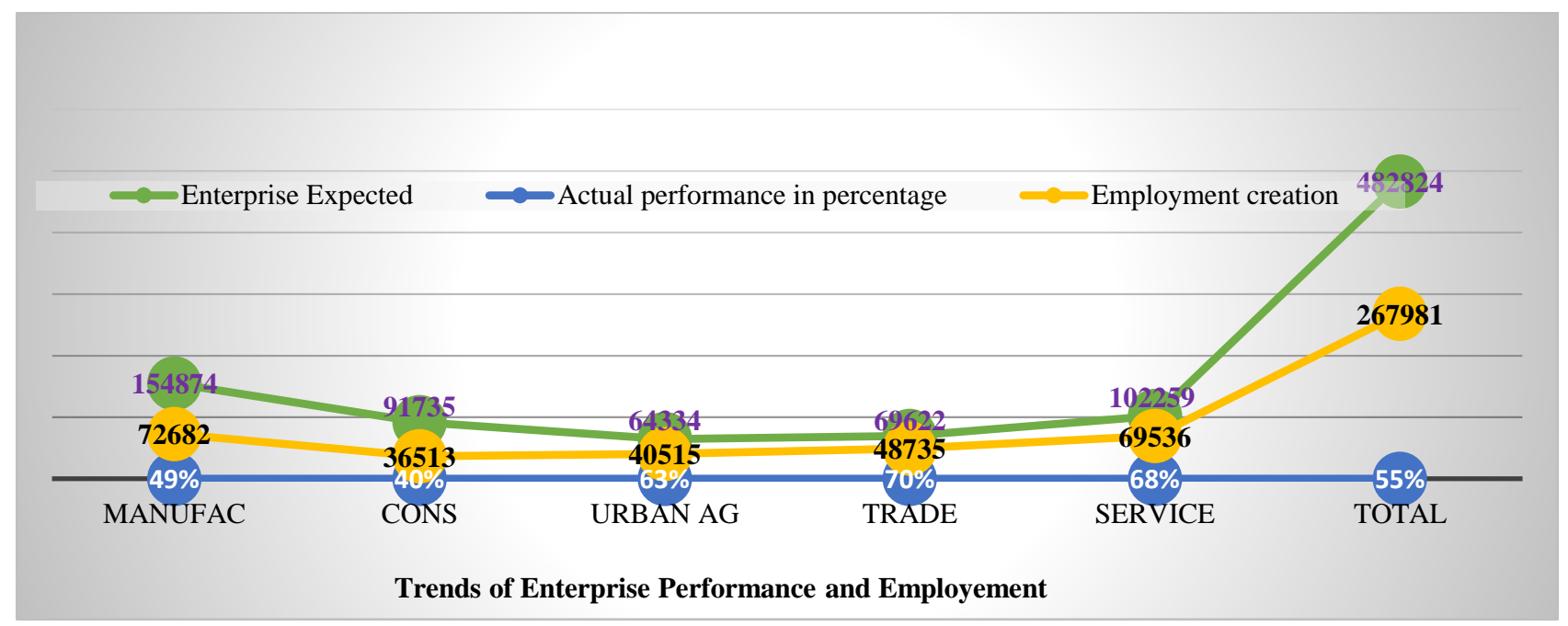

Fig 3: Employment creation

Figure 4 below shows that the market linkage of enterprise performance results indicates that credit distribution increases market linkage, employment creation, and enterprises' formation also increase in volume. When the credit distribution decreases, the market linkage, employment creation, and enterprises' formation decreases in volume. The credit distribution from 2011-2016 resulted in a deficient performance in the market linkage, employment creation, and enterprises' construction. 2017-2019 is very high and slows down to 2020. Simultaneously, the credit distribution from 2017-2019 in the same scenario was very high and slowed down to 2020. In 2020 credit distribution and Market linkage decreases due to violence of the peace throughout the country. From a marketing linkage point of view, it is critical for enterprise performance sustainability to expand its market share, increase employees' income, and reduce poverty towards unemployment.

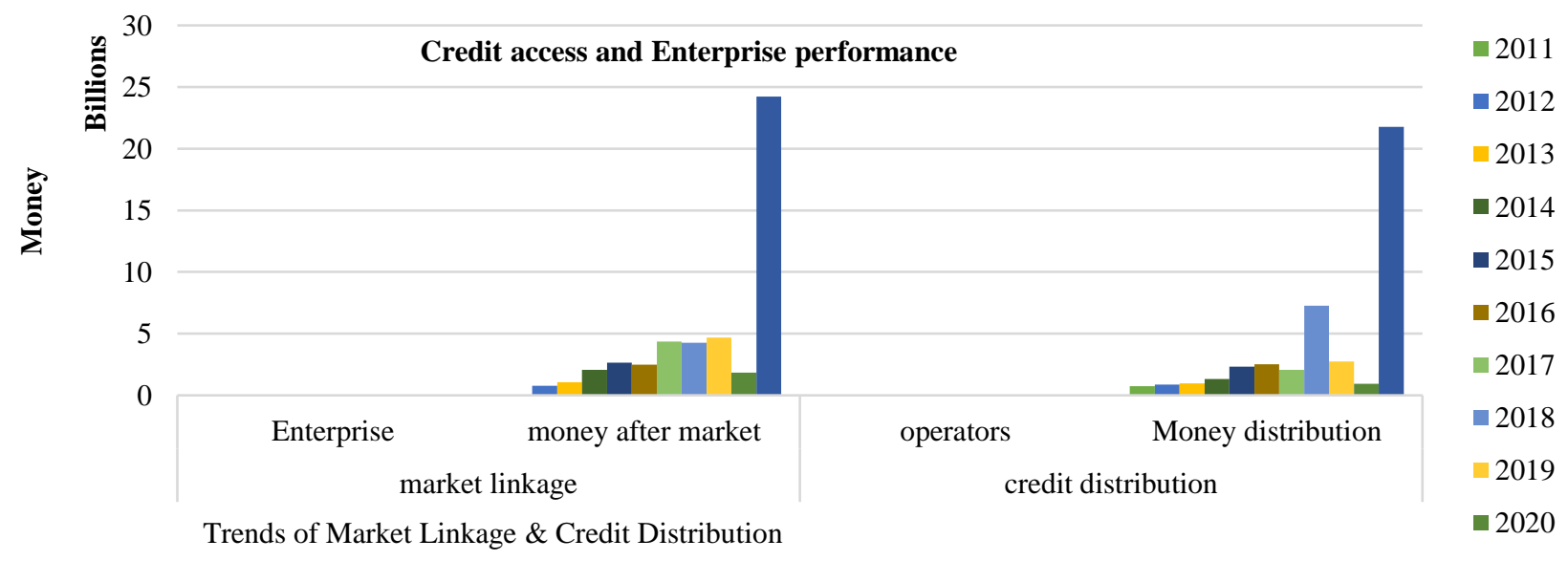

Market linkage and credit distribution

\subsection{Level of Respondents Trust}

Fig 5 below shows that the descriptive statistics can be summarized below the respondents' trust result. 26 items measured all independent variables by using the Likert scale towards enterprise performance.

Descriptive and multiple regression analysis was applied to estimate and analyze data. The research paper was supported by statistical treatment, SPSS, Amos, and STATA; the software was used. The information for this analysis was obtained from 2020 
small and micro-enterprises. The study's preliminary results were analyzed in the form of tables and figures, using straightforward percentages. The research targeted 383 questionnaires; however, 383 questionnaires were completed and returned (100\%).

The marketing linkage study measurements depend on government effectiveness due to consumer promotion, market efficiency rules, regulations, and accessibility of raw materials for enterprise performance. The main design of Likert scale,19(5\%) strongly disagree 132(34.5\%) disagree 111(29.0\%) neutral 35(9.1\%) agree 86(22.5\%) strongly agree. Many entrepreneurs formed structured partnerships between themselves and other stakeholders. Furthermore, the study discussed market linkage with research and training institutions and business connections among themselves, i.e., forward and backward customer connections. Consequently, most of the respondents reported terrible communication with their clients, including forwarding and backlinks. The open-ended question showed that most businesses buy substantial inputs for their production and service and offer their goods and vices to their consumers through their efforts without formal backward and demand for forwarding linkage. It indicates the role of government support implies gradual improvement in marketing support. But still, there is a gap between developing enterprise performance.

Industry category measuring variables Government product Technology, marketing, and financial support. From this point of view strongly disagree $29(7.6 \%)$ disagree $98(25.6 \%)$ neutral $141(36.8 \%)$ agree $113(29.5 \%)$ strongly agree 5 (5\%).From the respondents, response service trade and urban agriculture enterprises performance were good. While manufacturing and construction enterprises faced a lack of technology access, marketing integration and credit access were not accessed efficiently, and the lack of long-term loans.

Information communication technology measured with government access ICT for enterprises, other social media opportunities. The respondents response strongly disagree $3(8 \%)$ disagree $101(26.4 \%)$ neutral $35(9.1 \%)$ agree $212(55.4 \%)$ strongly agree $32(8.4 \%)$. The production was good due to service, trade, and urban agriculture, while manufacturing and construction companies faced communication problems to reach their customers. Credit access was measured by MFI access efficient amount of initial capital loan for entrepreneur, service delivery on time, and enterprise performance growth. The respondents response, 56(14\%) strongly disagree 86(22.5\%) disagree 3(8\%) neutral 141(36.8\%) agree 97(25.3\%) strongly agree. Most entrepreneurs agree with access credit on time and access efficient amount loan from the respondents' responses. But there is a significant number of entrepreneurs who disagree with service delivery and the amount of accessing loans for their business and positively affect enterprise performance.

Initial capital based on initial capital measured variables depend on microfinance accessing initial capital, loan repayment period. Respondents response based on the given questioners; strongly disagree 21(5.5\%) disagree 70 (18.3\%) neutral 127 $(33.2 \%)$ agree $164(42.8 \%)$ strongly agree 1 (3\%). This result shows that access to initial capital is questionable for enterprise performance's success with the required amount of credit based on business demand. The result implies that small and micro enterprises have an access credit gap based on the amount required over the time required.

Credit access is an obstacle to enterprise performance. It implies that, even though financing is indispensable for business expansion in any market, the proportion of companies that finance their business by borrowing from financial institutions is not easy to find. It indicates that the availability of credit to these companies is below the demand for them. In reality, as stated by most micro and small business owners, access to finance appears to be a very serious or significant barrier. Those entrepreneurs with access to structured finance did not secure the loan according to their request; instead, institutions offer loans below the entrepreneurial right. Therefore, even for the accepted proposals, which could be considered as a difficulty for the businesses, there are problems accessing credit, and inadequacy affects enterprise performance

Access to working premises (location) is measured by the business's appropriate location, the working place near raw material, and the working area (location). Government access infrastructure contributes to enterprise performance; the respondent's response 459 (11.7\%) strongly disagree, $104(27.2 \%)$ disagree, 11(2.9\%) neutral, $128(33.4 \%)$ agree, and $95(24.8 \%)$ strongly agree. From the result, there is a gap between working premises and government access because it is one challenge thatn enterprise performance positively affected. 


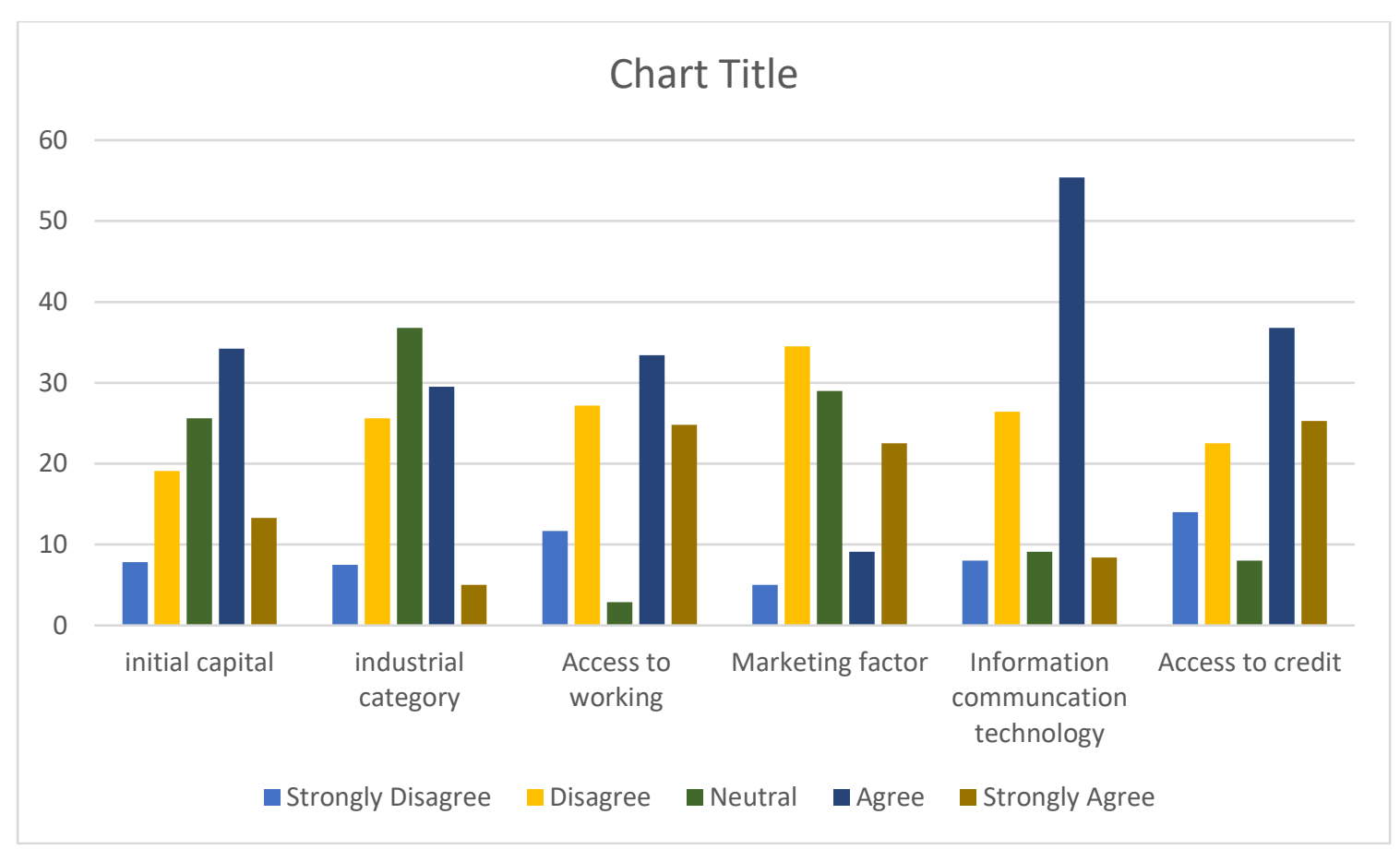

Fig 5 Level of Respondents Satisfaction

\subsection{Reliability Test}

The alpha coefficient for the 34 items is .922 , which suggests that there is a relatively high internal consistency of the pieces. "(Note that in most social science research circumstances, a reliability coefficient of .70 or higher is deemed "Acceptable"[52].

\begin{tabular}{|l|l|l|l|}
\hline Cronbach's Alpha & N of Items & N=sample size & Valid \% \\
\hline .922 & 26 & 383 & 100 \\
\hline
\end{tabular}

Table 3 Reliability statistics

The Correlations Matrix analysis, as shown in table 4, there is a strong and positive relationship between Variables (small and micro-enterprise performance with, industry category, and access to working premises, marketing linkage, information, and communication technology, and access to credit) with correlation coefficient value of $.716^{* *}, .700^{* *}, .780^{* *}, .539^{* *}, .706^{* *}, .678^{* *}$, respectively. The p-values of all variables are significant at the p-value $(.000)$ 
Correlations

\begin{tabular}{|c|c|c|c|c|c|c|c|c|}
\hline & & $\begin{array}{c}\text { Enterprise } \\
\text { Performance }\end{array}$ & Capital & Industry & Location & Market & ICT & $\begin{array}{c}\text { Access to } \\
\text { Credit }\end{array}$ \\
\hline $\begin{array}{l}\text { Enterprise } \\
\text { Performance }\end{array}$ & $\begin{array}{l}\text { Pearson Correlation } \\
\text { Sig. (2-tailed) } \\
\mathrm{N}\end{array}$ & 383 & & & & & & \\
\hline Initial Capital & $\begin{array}{l}\text { Pearson Correlation } \\
\text { Sig. (2-tailed) } \\
\text { N }\end{array}$ & $\begin{array}{r}716^{* *} \\
.000 \\
383 \\
\end{array}$ & $\begin{array}{r}1 \\
383 \\
\end{array}$ & & & & & \\
\hline $\begin{array}{l}\text { IndustryCateg } \\
\text { ory }\end{array}$ & $\begin{array}{l}\text { Pearson Correlation } \\
\text { Sig. (2-tailed) } \\
\text { N }\end{array}$ & $\begin{array}{r}.700^{* *} \\
.000 \\
383\end{array}$ & $\begin{array}{r}.420^{* *} \\
.000 \\
383\end{array}$ & $\begin{array}{r}1 \\
383\end{array}$ & & & & \\
\hline $\begin{array}{l}\text { Access to } \\
\text { Working }\end{array}$ & $\begin{array}{l}\text { Pearson Correlation } \\
\text { Sig. (2-tailed) } \\
\text { N }\end{array}$ & $\begin{array}{r}.780^{* *} \\
.000 \\
383\end{array}$ & $\begin{array}{r}.822^{* * *} \\
.000 \\
383\end{array}$ & $\begin{array}{r}.483^{* *} \\
.000 \\
383\end{array}$ & $\begin{array}{r}1 \\
383\end{array}$ & & & \\
\hline $\begin{array}{l}\text { Market } \\
\text { linkage }\end{array}$ & $\begin{array}{l}\text { Pearson Correlation } \\
\text { Sig. (2-tailed) } \\
\text { N }\end{array}$ & $\begin{array}{r}.539^{* *} \\
.000 \\
383\end{array}$ & $\begin{array}{r}.490^{* *} \\
.000 \\
383\end{array}$ & $\begin{array}{r}.304^{* * *} \\
.000 \\
383\end{array}$ & $\begin{array}{r}.516^{* *} \\
.000 \\
383\end{array}$ & $\begin{array}{r}1 \\
383\end{array}$ & & \\
\hline ICT & $\begin{array}{l}\text { Pearson Correlation } \\
\text { Sig. (2-tailed) } \\
\text { N }\end{array}$ & $\begin{array}{r}.706^{* *} \\
.000 \\
383\end{array}$ & $\begin{array}{r}.440^{* *} \\
.000 \\
383\end{array}$ & $\begin{array}{r}.520^{* *} \\
.000 \\
383\end{array}$ & $\begin{array}{r}.585^{* * *} \\
.000 \\
383\end{array}$ & $\begin{array}{r}.453^{* *} \\
.000 \\
383\end{array}$ & $\begin{array}{r}1 \\
383\end{array}$ & \\
\hline $\begin{array}{l}\text { Access to } \\
\text { Credit }\end{array}$ & $\begin{array}{l}\text { Pearson Correlation } \\
\text { Sig. (2-tailed) } \\
\mathrm{N}\end{array}$ & $\begin{array}{r}.678^{* *} \\
.000 \\
383\end{array}$ & $\begin{array}{r}.380^{* * *} \\
.000 \\
383\end{array}$ & $\begin{array}{r}.755^{* *} \\
.000 \\
383\end{array}$ & $\begin{array}{r}.463^{* * *} \\
.000 \\
383\end{array}$ & $\begin{array}{r}.301^{* * *} \\
.000 \\
383\end{array}$ & $\begin{array}{r}.647^{\text {** }} \\
.000 \\
383\end{array}$ & 383 \\
\hline
\end{tabular}

**. Correlation is significant at the 0.01 level (2-tailed).

Table 4 correlation Matrix

\subsection{Hypothesis testing Analysis}

Table 5 result implies that all independent variables were positively related to standard P-Value 0.05 and the work between .000 , which is an acceptable and significant impact on enterprise performance.

Hypothesis

\begin{tabular}{|l|l|c|c|c|c|}
\hline List of variables & Stated relationships of & $\begin{array}{l}\text { Chi-square } \\
\text { test results }\end{array}$ & \multirow{2}{*}{$\begin{array}{l}\text { Standards } \\
\text { of p-value }\end{array}$} & $\begin{array}{l}\text { Results of } \\
\text { p-values }\end{array}$ & Accept/reject \\
\cline { 5 - 6 } & variables & + & 0.05 & .000 & Accept \\
\hline Initial Capital & Positive & + & 0.05 & .000 & Accept \\
\hline Access to Working & Positive & + & 0.05 & .000 & Accept \\
\hline Marketing Factor & Positive & + & 0.05 & .000 & Accept \\
\hline ICT & Positive & + & 0.05 & .000 & Accept \\
\hline Access to Credit & Positive & &
\end{tabular}

Table 5 Decisions on Stated Hypothesis

Summary ${ }^{\mathrm{b}}$

\begin{tabular}{|c|c|c|c|c|c|c|c|c|c|c|}
\hline \multirow[t]{2}{*}{ Model } & \multirow[t]{2}{*}{$\mathrm{R}$} & \multirow[t]{2}{*}{ R Square } & \multirow{2}{*}{$\begin{array}{l}\text { Adjusted R } \\
\text { Square }\end{array}$} & \multirow{2}{*}{$\begin{array}{l}\text { Std. Error of the } \\
\text { Estimate }\end{array}$} & \multicolumn{5}{|c|}{ Change Statistics } & \multirow{2}{*}{$\begin{array}{l}\text { Durbin- } \\
\text { Watson }\end{array}$} \\
\hline & & & & & $\begin{array}{l}\text { R Square } \\
\text { Change }\end{array}$ & F Change & df1 & df2 & $\begin{array}{c}\text { Sig. F } \\
\text { Change }\end{array}$ & \\
\hline 1 & $.901^{\mathrm{a}}$ & .812 & .809 & .377 & .812 & 270.294 & 6 & 376 & .000 & 1.892 \\
\hline
\end{tabular}

b. Dependent Variable: Enterprise Performance

Table 6 Model Summary

As the model, the Summary result indicated, in Table 6, R Square's Value is .812 (81.2\%). The result implies the model is fitted. The dependent variable, enterprise performance, is positively affected by $81.2 \%$ by all variables. The independent variable with industry category, and access to working premises, marketing linkage, information, and communication technology, and access to credit) with a coefficient value of. .716**, .700**, .780**, .539**,.706**, and.678**, respectively. 
Table 7 ANOVA ${ }^{\mathrm{a}}$

\begin{tabular}{|ll|r|r|r|r|r|}
\hline Model & & Sum of Squares & Df & Mean Square & F & Sig. \\
\hline \multirow{4}{*}{1} & Regression & 229.967 & 6 & 38.328 & 270.294 & $.000^{\mathrm{b}}$ \\
& Residual & 53.317 & 376 & .142 & & \\
& Total & 283.285 & 382 & & & \\
\hline
\end{tabular}

a. Dependent Variable: Enterprise Performance

b. Predictors: (Constant), Access to Credit, Market, Capital, ICT, Industry, Location

Table 7 results show that there is a significant relationship between the input factors and enterprise performance, $\mathrm{F}(6,376)$ $=270.294, \mathrm{p}<0.001$

\subsection{Regression Coefficients Analysis}

Based on the regression table, when one unit of each independent variable increases, the dependent variable increases by the calculated coefficient values. It means assuming all things are constant when the variable enterprise performance increases by one unit, independent variable. The variable Initial capital increases by .166 , enterprise performance also increased. The industry category increase by .239 , the outcome variable enterprise performance also increases. Access working premises increase by .214, enterprise performance also improved. Increase in marketing factor by 0.65 , also increase in enterprise performance. Enterprise performance has also increased by .180 in information technology. Enterprise performance has also increased access to the credit factor by .115. All variables are significant at a p-value of .000.

From the normal point of view of variance, an inflation factor less than 1 is not correlated; between 1 and 5 are accepted (Michael et al. 2015). The VIF value of this study is between 1.5 to 4.85 . So, there is no mu; collinearity problem among variables. It also indicates the independent variables are moderately associated with the dependent enterprise performance

\begin{tabular}{|c|c|c|c|c|c|c|c|c|}
\hline \multicolumn{9}{|c|}{ Coefficients $^{\mathrm{a}}$} \\
\hline \multirow{2}{*}{\multicolumn{2}{|c|}{ Model }} & \multicolumn{2}{|c|}{$\begin{array}{c}\text { Unstandardized } \\
\text { Coefficients } \\
\end{array}$} & \multirow{2}{*}{$\begin{array}{c}\text { Standardized } \\
\text { Coefficients }\end{array}$} & \multirow[t]{2}{*}{$\mathrm{t}$} & \multirow[t]{2}{*}{ Sig. } & \multicolumn{2}{|c|}{ Collinearity Statistics } \\
\hline & & $\mathrm{B}$ & Std. Error & & & & Tolerance & VIF \\
\hline \multirow{7}{*}{1} & (Constant) & .028 & .082 & & .339 & .735 & & \\
\hline & $\begin{array}{l}\text { Initial } \\
\text { Capital } \\
\end{array}$ & .166 & .030 & .221 & 5.502 & .000 & .312 & 3.209 \\
\hline & $\begin{array}{l}\text { Industry } \\
\text { category }\end{array}$ & .239 & .033 & .259 & 7.367 & .000 & .405 & 2.467 \\
\hline & $\begin{array}{l}\text { Access } \\
\text { working }\end{array}$ & .214 & .038 & .247 & 5.596 & .000 & .257 & 3.898 \\
\hline & $\begin{array}{l}\text { Market } \\
\text { linkage }\end{array}$ & .065 & .019 & .094 & 3.451 & .001 & 680 & 1.472 \\
\hline & ICT & .180 & .029 & .208 & 6.241 & .000 & .449 & 2.227 \\
\hline & $\begin{array}{l}\text { Access to } \\
\text { Credit }\end{array}$ & .115 & .036 & .122 & 3.169 & .002 & .340 & 2.939 \\
\hline
\end{tabular}

a. Dependent Variable: Enterprise Performance

Table 8 coefficient

\subsection{Normality Test Analysis}

As figure 6, the normality test shows the distribution of the data is normal. Figure 7 p-plot figure revealed that the data is linear and nearest to the line. A standard probability plot of the residuals is concerned with the error terms' normality: to conclude that the error terms are normally distributed if the resulting plot is roughly linear. 


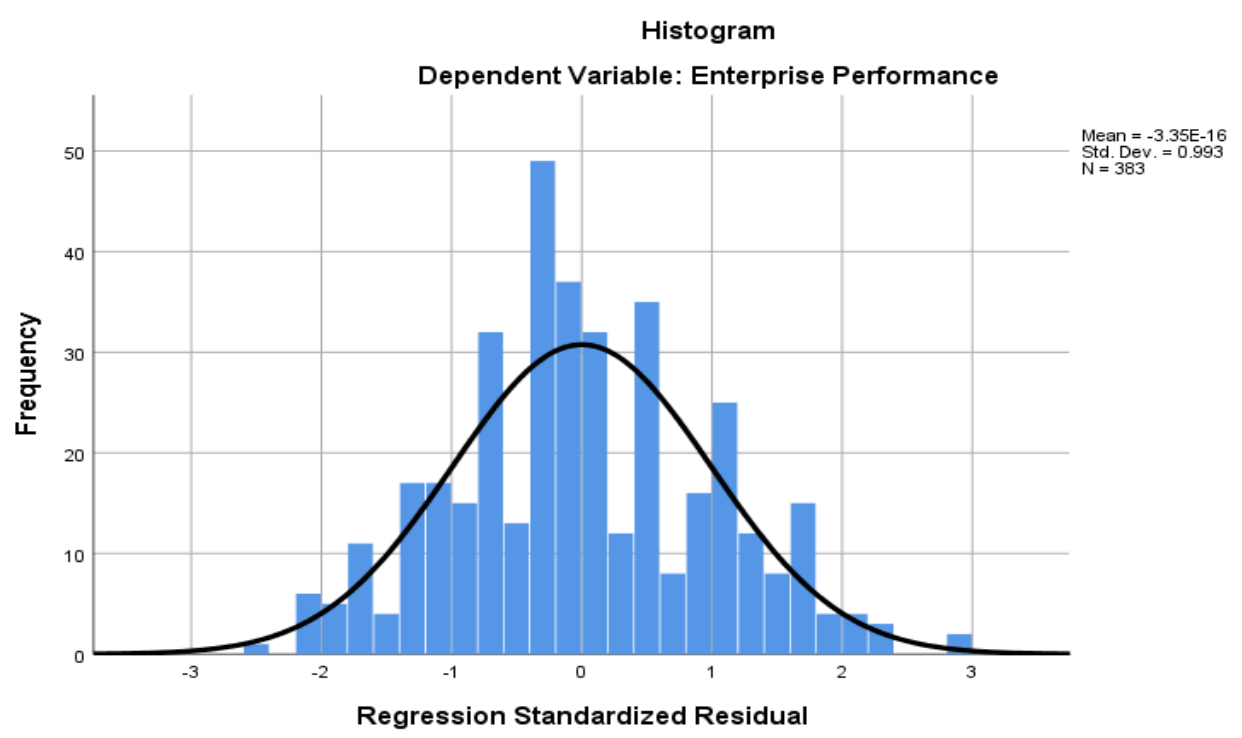

Fig 6: Normality test graph

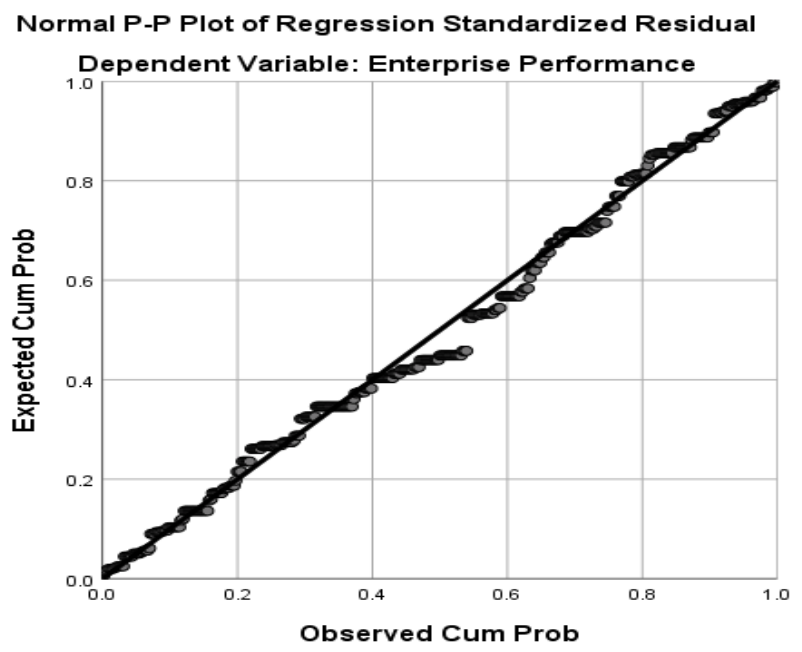

Figer 7: Normal P-Plot of Regression

\section{Conclusion and Recommendation}

The study examined the determinant factors affecting small and micro enterprises (SMEs) performance using Six predictive variables in the Amhara Region, Ethiopia. Descriptive and explanatory research methods were applied and both primary and secondary data acquired using a linear regression model. Based on the reviewed literature and empirical studies finding, the study concluded the following key points.

(1) The study's findings indicate that the dependent variable enterprise performance and the independent variables have a positive relationship and statistically significant at p-value (.000). The outcome variable enterprise performance is affected by the predictive variable; initial capital, access to credit, Industry category, market linkage, ICT adoption, and access working premises (location).

(2) From the findgs of this research, 81.2 percent of determinant factors marketing factor, access working premises(location), initial capital, access credit, and ICT adoption affected positively small and microenterprise performance. But there were 18.8 percent unknown variables that need further research for the future. On the other side, this research data were collected from small and micro-enterprises. It will further research based on enterprise agency employees, leaders, microfinance leaders, and employees. Clusters are very important for poverty reduction. 
Economic growth and growing employment income levels lead to poverty reduction through job creation and income generation for the poor, enabling entrepreneurs to mobilize limited resources, increase business productivity, and enter wider markets through collective action opportunities. It is important to conduct further research towards poverty-based consideration of cluster development strategies designed and implemented in the Amhara region.

(3) The regression analysis result revealed that SMEs with access to better initial capital have effective performance. In comparison, those who have no more initial capital faced a sustainability problem in their business performance. The initial capital is not affordable in their operation process due to the influence of inflation. To avert these problems, government, microfinance institutions, and others responsible bodies should be take corrective measures. To improve performance of job creation should increase the loan amount and long-term loan and design machine lease policy. The Machine Lease Strategy is important for enterprise performance to sustainability of entrepreneuers. Machine leasing is a very important asset-based financing and allows SMEs to expand their access to short and medium-term funding from an economic perspective.

Further research on machine leasing as a solution for SMEs. While in the Amhara region, there is a shortage to access sufficient technology for small and micro-enterprises. It needs high Government intervention, and additional research will be conducted in the Amhara region

(4) SMEs who have an opportunity for the Market linkage with government and non-governmental organizations grow faster than others with no chance to market association with government and non-government organizations. SMEs in rural areas have a market linkage in exhibitions and bazaars at urban centers to sell and promote their products and service. To strengthening sustainable market linkage at the rural center s, the government should establish connections with cooperatives, unions, and institutions. Additionally, the government should take corrective action to facilitate entrepreneurial marketing competition, product quality, service delivery, packaging, and leveling their products. The other market linkage analysis findings indicate that; companies with effective loans can sustain the competitive market increase in volume. In contrast, enterprises that have not got loans to decrease market competition and employment growth.

(5) Working premises have a vital role in enterprise performance. Access to working premises by the government and family in line with proximity to customers and raw materials grow easily. Whereas entrepreneurs who used in the rental system and far from customers, raw materials are not successful. To solve the existed problems of working premises, the government should apply a cluster development approach, which solves the supply of land, infrastructure, shed, and power energy.

(6) SMEs who have access to ICT, including the internet, social media, radio, television, printing media, change their business operation in different information dissemination. While entrepreneurs who have no access to ICT exposed to a lack of information. Therefore, government and responsible bodies should solve the ICT limitation of SMEs.

\section{Data Availability Statement}

Due to data availability, the process of collected secondary and primary data ensuring that is available. Primary data from respondents and secondary data from regional government 10-year performance by assuring from TVED Bearuea. The researchers analyze those data by using SPSS and Amos software.

\section{Reference}

1 J. Mbugua, S. Mbugua, and M. Wangoi, "Dress Making," Pdfs.Semanticscholar.Org, vol. 4, no. 5, 2013 , pp. $285-293$.

2 S. C. Gherghina, M. A. Botezatu, A. Hosszu, and L. N. Simionescu, "Small and medium-sized enterprises (SMEs): The engine of economic growth through investments and innovation," Sustain., 2020,vol. 12, no. 1.

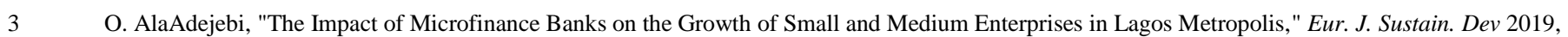
vol. 8 , no. 3 , p. 261.

4 A. A. Esubalew and A. Raghurama, "Micro, Small and Medium Enterprises(MSMEs)Development Strategies in Ethiopia: Retrospective and Prospective Analysis," Iracst - Int. J. Commer. Bus. Manag. 2020., vol. 6, no. 1, pp. 2319-2828.

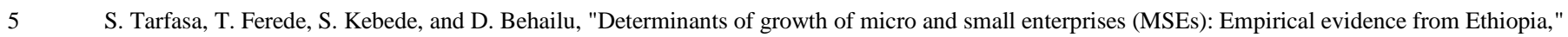
World Trade Inst. 2016. pp. 1-29.

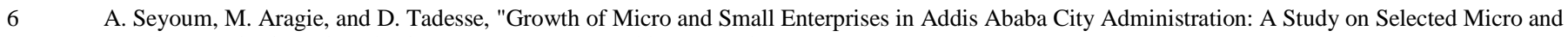
Small Enterprise in Bole Sub City," Int. J. Sci. Res. Publ. 2016, vol. 6, no. 1, pp. 581-2250.

7 H. T. Woldeyohanes, "Agris online Papers in Economics and Informatics Dimensions and Determinants of Growth in Micro and Small Enterprises : Empirical Evidence from Mekelle City , Ethiopia 2014,VI, no. 3, pp. 104-115,

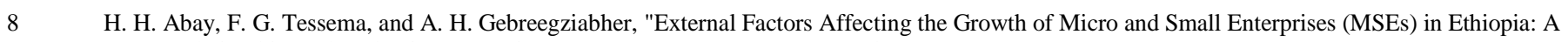
Case Study in Shire Indasselassie Town, Tigray," Eur. J. Bus. Manag, 2014, vol. 6, no. 34, pp. 134-146.

9 H. Tefera, A. Gebremichael, and N. Abera, "Growth Determinants of Micro and Small Enterprises : Evidence," 2013 ,vol. 4, no. 9, pp. 122-134. 
M. Adam, "Constraints and Growth Potentials of Micro and Small Enterprises : Case from Mekelle City," J. Econ. Sustain. Dev. 2014, vol. 5, no. 24, pp. 133-140.

D. Alemayehu, "Determinants of Micro and Small Enterprises Growth: The Case of Durame Town, Kembata Tembaro Zone, Southern Nations and Nationalities and Peoples Region, Ethiopia, 2016," Int. J. Bus. Econ. Res, 2016, vol. 5, no. 5, p. 161.

G. T. Abebe, S. Caria, M. Fafchamps, P. Falco, S. Franklin, and S. Quinn, "Curse of Anonymity or Tyranny of Distance? The Impacts of Job-Search Support in Urban Ethiopia," NBER Work. Pap 2016, no. June, p. 72.

G. Abara and T. Banti, "Role of Financial Institutions in the Growth of Micro and Small Enterprises in Assosa Zone," Int. J. Sci. Res. 2017. vol. 6, no. 3, pp. 852-856.

M. Momba, "the Impact of Microfinance on Small and Medium Enterprises Growth in Morogoro Moris Mhidini Momba a Dissertation Submitted in Partial Fulfillment of the Requirements for the Degree of Master of Science in Economics of the Open University of Tanzania," 2013.

C. Chittithaworn, A. Islam, T. Keawchana, and D. H. M. Yusuf, "Factors affecting business success of small \& medium enterprises (SMEs) in Thailand," Asian Soc. Sci., 2011, vol. 7, no. 5, pp. 180-190,

B. A. Kinde, "Financial Sustainability of Microfinance Institutions ( MFIs ) in Ethiopia," Eur. J. Bus. Manag2012, vol. 4, no. 15, pp. 1-11.

F. Nega, "Small and Medium Enterprise Access to Finance in Ethiopia : Synthesis of Demand and Supply," no. February, 2016.

S. N. Kebede, "Determinants of Micro and Small Enterprises' Access to Finance," 2014, vol. 4, no. 21, pp. 90-104,

C. Dana, "The Role of Microfinance," Www.Kristof.Nlogs.Nytimes.Com, 2009.

W. Belachew, " The effect of Omo Microfinance credit on the growth of Micro and Small enterprises in Hossana Town . By: A Thesis submitted to the Department of Accounting and Finance of Addis Ababa," 2019.

N. Larson and M. Story, The adolescent obesity epidemic: Why, how long, and what to do about it, 2008, vol. 19, no. 3.

Briman, "social research methodology," book, vol. 4, no. 2, p. 800, 2557.

MUDHCo, "National Report on Housing \& Sustainable Urban Development," pp. 1-75, 2014.

J. Watson, "Businesses : Relating Outputs to Inputs E ] p," pp. 91-100, 2002.

S. Abubakar and A. S. Junaidu, "External Environmental Factors and Failure of Small and Medium Enterprises in Kano Metropolis," Asian J. Econ. Empir. Res. 2019, vol. 6, no. 2, pp. 180-185,

D. G. Belay and M. Y. Kifle, "The Roles and Challenges of Micro and Small Enterprises in Urban Employment Creation in Ethiopia," Int. J. Polit. Act. Engagem. 2020. vol. 7, no. 1, pp. 1-22.

T. Cherkos, M. Zegeye, S. Tilahun, and M. Avvari, "Examining significant factors in micro and small enterprises performance: case study in Amhara region, Ethiopia," J. Ind. Eng. Int. 2018., vol. 14, no. 2, pp. 227-239.

W. Munyanyi and A. Mapfumo, "Factors Influencing Crowdfunding Plausibility in Post Hyperinflationary Zimbabwe," J. Entrep. Bus. Innov. 2016, vol. 3, no. 1, p. 18,

S. Bhattacharya and B. R. Londhe, "Micro Entrepreneurship: Sources of Finance \& Related Constraints," Procedia Econ. Financ2014, vol. 11, no. 14, pp. 775-783.

E. Papadaki and B. Chami, "Growth determinants of micro-businesses in Canada," Small Bus. Policy Branch Ind. Canada, p. $55,2002$.

S. R. and B. K. TekleLeza, " Research Article Determinants of Employment Growth Micro and small enterprises in Wolayta Zone Ethiopia Rajan and 3 Berhanu Kuma of Rural Development and Agricultural Extension, Ph . Din Livelihood and Poverty Reduction, " 2016.

M. Victoria, "Determinants of Small and Medium Enterprises Failure in Zimbabwe: a Case Study of Bindura," Int. J. Econ. Res2011, vol. 02, no. 05, pp. 82-89.

A. M. Yeboah, "Determinants of SME growth: An empirical perspective of SMEs in the Cape Coast," no. January 2015.

E. Munjeyi, "What Has Accounting Information Got to Do with SMEs in Zimbabwe? ( A Zimbabwe' s Rural SMEs Focus )," 2017, vol. 8, no. 19, pp. $13-17$.

F. Wolde and E. Geta, "Determinants of Growth and Diversification of Micro and Small Enterprises : The Case of Dire Dawa, Ethiopia," Dev. Ctry. Stud. 2015, vol. 5, no. 1, pp. 61-76.

M. Oppong, A. Owiredu, and R. Q. Churchill, "Micro and Small Scale Enterprises Development in Ghana," Eur. J. Account. Audit. Financ. Res. 2014, vol. 2, no. 6, pp. 84-97.

G. D. Daniel and D. Getu, "Farmers knowledge, perceptions and management practices of termites in the central rift valley of Ethiopia," African J. Agric. Res. 2015, vol. 10, no. 36, pp. 3625-3635.

S. K. Ogubazghi and W. Muturi, "The Effect of Age and Educational Level of Owner/Managers on SMMEs' Access to Bank Loan in Eritrea: Evidence from Asmara City," Am. J. Ind. Bus. Manag. 2014, vol. 04, no. 11, pp. 632-643.

C. Amentie, E. Negash, and L. Kumera, "The Effects of Firms' Characteristics on the Growth of Medium and Small Business in Developing Country (Case Study Ethiopia)," Glob. J. Manag. Bus. Res. 2016, vol. 16, no. 6.

B. Assefa, A. Zerfu, and B. Tekle, Identifying Key Success Factors and ConstraintsiIn Ethiopia' S Mse Development: An Exploratory Research by Berihu Assefa, Abebaw Zerfu, and Addis Ababa, Ethiopia October 2014, no. October.

A. Luther Ntim, "Accounting Practices and Control Systems of Small and Medium Size Entities: A Case Study of Techiman Municipality," J. Financ. Account. 2014, vol. 2, no. 3, p. 30.

R. Lensink, R. Mersland, N. T. H. Vu, and S. Zamore, "Do microfinance institutions benefit from integrating financial and nonfinancial services?," Appl. Econ. 2018, vol. 50, no. 21, pp. 2386-2401.

J. Adams, H. T. A. Khan, and R. R. \& D. White, Research Methods for Graduate Business and Social Science Students. SAGE Publications India Pvt Ltd, 2012. 
12, no. 1, pp. 103-122.

45 J. W.Crewell, educational research. 2012.

46 G. G. Guilbault and M. Hjelm, Nomenclature for automated and mechanised analysis, 1989.vol. 61, no. 9.

47 Morgan, "Activities of human RRP6 and structure of the human RRP6 catalytic domain," Rna, 2011, vol. 17, no. 8, pp. $1566-1577$.

48 M. Gebreeyesus, "Growth of Micro-Enterprises: Empirical evidence from Ethiopia," Ethiop. Dev. Res, 2007, Inst., no. May, pp. 1-21.

49 TekleLeza, S. Rajan, and B. Kuma, "Determinants of Employment Growth of Micro and Small Enterprises in Wolaita Zone, Ethiopia," Int. J. Curr. Res. 2016, vol. 8, no. 12, pp. 43177-43186.

50 D. N. Gujarati and D. C. Porter, Basic Econometrics, 5th ed. Americas, New York, NY, 10020.: The McGraw-Hill Companies, Inc., 2009.

51 L. J. Cronbach, "Coefficient alpha and the internal structure of tests," vol. 42, no. 1, pp. 1-10, 1951.

52 Michael Olusegun Akinwande, Hussaini Garba Dikko, and Agboola Samson, "Variance Inflation Factor: As a Condition for the Inclusion of Suppressor Variable(s) in Regression Analysis," Open J. Stat. 2015, vol. 05, no. 07, pp. 754-767. 